\title{
Freshwater crayfish distribution update and maps for Greece: combining literature and citizen-science data
}

\author{
Costas Perdikaris ${ }^{1, *}$, Evangelos Konstantinidis ${ }^{1}$, Christos Georgiadis ${ }^{2}$ and Antonín Kouba ${ }^{3}$ \\ ${ }^{1}$ Fisheries Department, Regional Unit of Thesprotia, Region of Epirus, P. Tsaldari 18, 46100 Igoumenitsa, Greece \\ 2 Section of Zoology-Marine Biology, Department of Biology, National and Kapodistrian University of Athens, \\ 15784 Panepistimioupolis, Greece \\ ${ }^{3}$ Faculty of Fisheries and Protection of Waters, South Bohemian Research Center of Aquaculture and Biodiversity \\ of Hydrocenoses, University of South Bohemia in České Budějovice, Zátiší 728/II, CZ-389 25 Vodňany, Czech Republic
}

\begin{abstract}
Crayfish are charismatic creatures of high interest to humans, among others playing key roles in freshwater ecosystems. Considering the significance of indigenous crayfish species (ICS) as well as the risks posed by non-indigenous crayfish species (NICS) that may dissemite a crayfish plague pathogen Aphanomyces astaci, astacological research has advanced particularly in Europe. In this context, crayfish distribution patterns are of fundamental importance. Focused on all crayfish established in the Greek wild, we provide an updated distribution and maps, combining extensive review of existing literature as well as newly emerging sources, largely represented by increasingly important citizen-science data. Obtained results demonstrate that ICS, mainly the Astacus astacus and Austropotamobius torrentium, remain relatively well settled in the country. The last ICS, Astacus leptodactylus, was translocated in few places outside its native range, leading to the formation of new flourishing populations and at least in one case it sustains commercial exploitation. Concerning NICS, a single population of Pacifastacus leniusculus is also established in the artificial lake Agra (Region of Central Macedonia) and keeps spreading. Unfortunately, there are only few methods under a very narrow range of conditions making successful eradication of unwanted NICS populations feasible. This option is even more difficult as this population is commercially exploited and traded. Since further potentially problematic NICS are also pet-traded in the country, educating public and communicating highlighted issues are the most effective ways limiting their releases and consecutive establishment in the wild.
\end{abstract}

Keywords: Astacidae / biogeography / indigenous species / invasive species / mapping

Résumé - Mise à jour de la distribution des écrevisses d'eau douce et cartes pour la Grèce : combinaison de données de littérature et de données de la science citoyenne. L'écrevisse est une créature charismatique d'un grand intérêt pour les humains, entre autres, qui joue un rôle clé dans les écosystèmes d'eau douce. Compte tenu de l'importance des espèces indigènes d'écrevisses (ICS) et des risques que représentent les espèces non indigènes d'écrevisses (NICS) qui peuvent disséminer un agent pathogène de la peste des écrevisses Aphanomyces astaci, la recherche astacologique a progressé particulièrement en Europe. Dans ce contexte, les schémas de distribution des écrevisses sont d'importance fondamentale. Centré sur toutes les écrevisses établies dans les milieux naturels grecs, nous fournissons une distribution et des cartes mises à jour, combinant une revue approfondie de la littérature existante ainsi que de nouvelles sources émergentes, largement représentées par des données de plus en plus importantes de la science citoyenne. Les résultats obtenus montrent que les ICS, principalement Astacus astacus et Austropotamobius torrentium, restent relativement bien implantés dans le pays. Le dernier ICS, Astacus leptodactylus, a été transféré en quelques endroits en dehors de son aire de répartition naturelle, ce qui a entraîné la formation de nouvelles populations florissantes et, dans un cas au moins, fait l'objet d'une exploitation commerciale. En ce qui concerne les NICS, une seule population de Pacifastacus leniusculus est également établie dans le lac artificiel Agra (région de Macédoine centrale) et continue à se répandre. Malheureusement, il n'existe que peu de méthodes dans une gamme très étroite de conditions rendant

\footnotetext{
*Corresponding author: cperdik74@yahoo.gr
} 
possible l'éradication réussie des populations de NICS indésirables. Cette option est d'autant plus difficile que cette population est exploitée commercialement et transportée. Comme d'autres espèces animales nuisibles potentiellement problématiques sont également commercialisées dans la région, l'éducation du public et la communication sur ces questions importantes constituent les moyens les plus efficaces de limiter leurs rejets et leur établissement consécutif dans la nature.

Mots-clés : Astacidae / biogéographie / espèces indigènes / espèces envahissantes / cartographie

\section{Introduction}

Freshwater crayfish research has substantially advanced during the last decade in Europe and beyond. In particular, crayfish zoogeography and distribution has been updated (at least in macro-scale) based on concerted efforts of various expert groups in different countries (see the pan-European review data and maps in Holdich $(2002,2003)$, Souty-Grosset et al. (2006), and Kouba et al. (2014)). The earliest records on exact crayfish distribution for Greece date back to the 19th century, based on Astacus leptodactylus sensu lato samples deposited to the Natürhistorisches Museum in Vienna, Austria (Machino and Holdich, 2006). Other publications referred mainly to restricted geographical areas, focused on one or hardly two species (Balss, 1928; Karaman, 1963; Bott, 1972; Koukoura, 1973; Albrecht, 1982; Kinzelbach, 1986; Theocharis, 1986) and although extremely valuable, they generally failed to provide an overview and at the same time detailed biogeographical picture of crayfish presence in the country. However, Greece followed the general trend and the related publications increased sharply during the 2000s (see for example Koutrakis et al., 2005a, 2007; Perdikaris et al., 2005a, b, 2007; Machino and Holdich, 2006; Perdikaris, 2009).

Astacological work and the existing literature on crayfish distribution have documented that three indigenous crayfish species (ICS), Astacus astacus (L.), Austropotamobius torrentium (Schrank) and A. leptodactylus, remain present and a single non-indigenous crayfish species (NICS) Pacifastacus leniusculus (Dana) became established in the Greek freshwaters. Most populations of $A$. astacus and $A$. torrentium, are mainly present in isolated areas and crayfishproductive waters of the past, disappeared in some cases due to pollution, eutrophication, habitat alterations and crayfish plague with reported incidents in 1982, 1992 and 2004 (Alderman, 1996; Nikolaou, 2004; Savvidis, 2005a, b; Koutrakis et al., 2007). It is also reasonable to expect that some crayfish plague outbreaks took place but remained unnoticed in the meantime. Nevertheless, A. astacus and $A$. torrentium populations are still present over relatively large areas of the country.

Distribution information and data on aquatic species including crayfish, are increasingly generated not only by aquatic biologists and astacologists, but also from citizenscientists. Divers, photographers, fishermen, vacationers, community groups, school classes, outdoor sporting and recreational clubs, natural history societies and local people represent a huge workforce and a source of skills, local knowledge and computational power. They observe and collect valuable data which are frequently appropriate for species determination and/or ecosystem/site location. This type of contribution to the scientific knowledge basis was recently applied with success for example in the distribution and monitoring of non-indigenous and invasive marine species in the USA (Delaney et al., 2008) and Greece (Zenetos et al., 2013). Moreover, smartphone applications have been developed for the field identification of European crayfish (De Vaugelas et al., 2011) and even a student-based citizen science program was conducted to remove invasive crayfish (Garcia et al., 2015).

The current work aimed to conduct a distribution update including country-wide maps for all crayfish species present in Greece using a compilation of all available data. The latter is particularly based on internet sources (citizen-science), while a series of examples are provided.

\section{Materials and methods}

Crayfish distribution data were mined from the existing literature. Additional data were also gathered during 20132016 mainly through internet search (videos from YouTube ${ }^{\mathrm{TM}}$, photos and posts from Facebook ${ }^{\mathrm{TM}}$ and the Google ${ }^{\mathrm{TM}}$ search engine). After assessment, the most credible findings were included in a dataset which was used to generate maps for each species using GIS software (ArcMap 10.1 ${ }^{\mathrm{TM}}$, Esri, USA).

\section{Results}

\subsection{Selected cases of crayfish presence and species distribution maps}

The collected data (i.e., records) presented in this paper can be classified into categories of their respective sources. In several cases, more than one source category was recorded for the same locality (e.g., reference and video). We thus created a graph, cumulatively depicting the instances of each record according to their source for each species. From this graph (Fig. 1) it is clear that most of the records refer to A. astacus (56\% of total records) while P. leniusculus adds only 6 records (4\%) to the total. Interestingly, the records deriving from published sources, account for just over half of the total number of records $(57 \%)$, while the social media and other internet-based records reach $26 \%$.

\subsubsection{Astacus astacus}

Astacus astacus is distributed in the Regions of Central and Western Macedonia, Epirus, Thessaly, Sterea Ellada, Western Greece and Peloponnisos in three main, disconnected distribution zones (Fig. 2). The species is found in a variety of lentic and lotic ecosystems. The main lake (natural and artificial) systems with either historical and/or current presence of the species are Prespes, Vegoritida, Doirani, Pamvotida, Tzaravina, Aoos dam, Tavropos dam and a tributary of the 


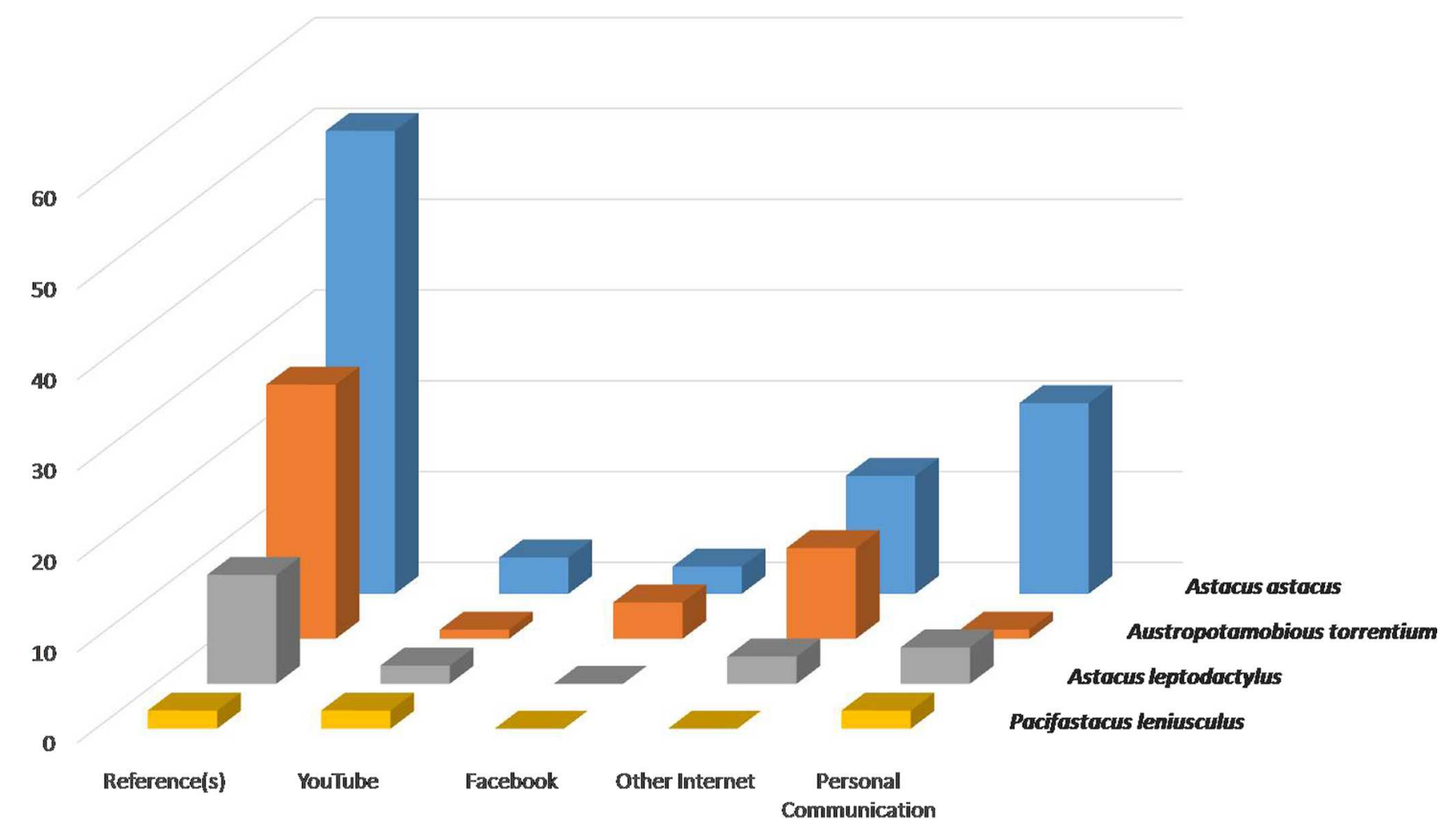

Fig. 1. Origin of data sources (i.e., from literature and citizen-science) for all freshwater crayfish species.

dried lake Ksyniada. Moreover, translocated populations are present in two lakes in the Peloponnisos peninsula. Major rivers systems related to A. astacus are Axios, Loudias, AoosVoidomatis, Kalamas, Arachthos, Louros, Acheron, Acheloos, Pinios, Spercheios and Kifissos (in Viotia). Its northern distribution area overlaps with that of $A$. torrentium, as both species have been recorded sympatrically at least from the catchment of Axios river to the catchment of Prespes lakes. Both species are also present in FYROM and Albania. Moreover, one small overlapping zone is also evident, after the recent collection of specimens in mountain streams on Olympus mountain, given that $A$. torrentium was reported from a location south of Olympus (Daphni spring, right bank of the river Pinios, Tempi valley; Kinzelbach, 1986; Machino and Holdich, 2006).

Internet search led to the discovery of new $A$. astacus populations previously unknown to the scientific community. Two of them are located in the northern part of the Peloponnisos peninsula in two mountain lakes with subalpine characteristics. The first is located in the artificial Doxa lake created during the late 1990s in the Region of Western Greece (mean surface of 100 ha, $872 \mathrm{~m}$ a.s.1., max depth $38 \mathrm{~m}$ ) and the second in Tsivlou lake in the Region of Peloponnisos (total surface of 20 ha, $708 \mathrm{~m}$ a.s.1., max depth $80 \mathrm{~m}$ ), which was formed during 1913 after a massive earth sliding which blocked a brook. The presence of an abundant crayfish population in Doxa lake was first mentioned by members of the Amateurs Divers Association in 2007, without posting any photo (Fig. 2, point 62). Subsequent posts (Fig. 2, points 61 , included high quality photos, including blue-colored specimens. The presence of the population in Doxa lake (without identification to the genus or species level) was also published during 2013 in a travelling/tourist guide (Ladas, 2013) and on a video posted on YouTube (Fig. 2, point 62). According to an environmental education report for Tsivlou lake (Papakonstantinou, 2003), the crayfish were translocated during the last 20 years, without any more details (Fig. 2, point 61). On the other hand, in a recent work by Laggis et al. (2017), the origin of the founder populations in Doxa lake is stated as unknown. Therefore, the presence of the species in the water courses prior to damming cannot be ruled out. In contrary, the population in Tsivlou lake was translocated from an unknown location and these two populations represent genetically different and distinct genetic clusters separated by genetic barriers (Laggis et al., 2017).

The presence of crayfish in Vegoritida lake, Region of Western Macedonia is shown on a video posted on YouTube, presenting a specimen in the water, but its low sharpness does not allow unambiguous identification (Fig. 2, point 13). Astacus astacus was almost extirpated from the lake during the 1980s' and 1990s' from unknown reasons, but it is still present in low abundance, mainly in the deeper parts of the lake. Published data relating to this species (mentioned as A. astacus balcanicus) for this particular ecosystem date back to the 1970s' (Koukoura, 1973). It has been recently confirmed by sampling (Laggis et al., 2017). Moreover, an interesting information, but ignored by the literature for presence of the species (also mentioned as A. a. balcanicus) in the springs of Arapitsa river (Vermio mountain), tributary of Aliakmonas river ( $3 \mathrm{~km} \mathrm{SW}$ of the city of Naousa) was detected in the work of Koukoura (1973) (Fig. 2, point 12). 


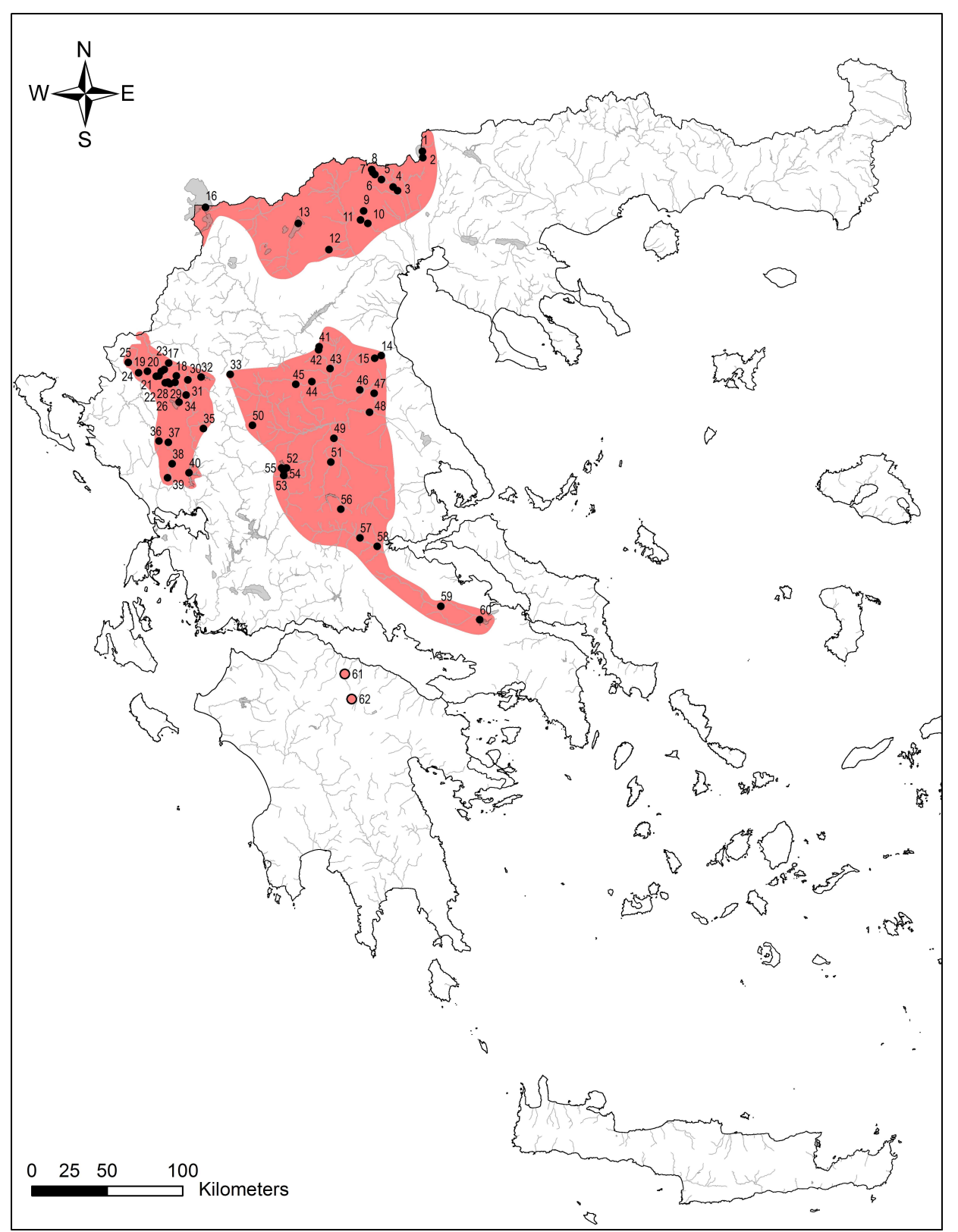

Fig. 2. Distribution areas of Astacus astacus in Greece. Numbers with details follow the sequence of Table 1, Supplementary Material. Original layers from www.geodata.gov.gr.

A new $A$. astacus population was identified exclusively by posted photos from Armampei dam, close to the village Akri Elassonas, Region of Thessaly (Fig. 2, point 41). This dam was stocked by locals with $A$. astacus originating from a nearby small pool/brook (named Tsairisio in the local dialect) which is fed by a small waterfall (catchment of river Pinios) (Fig. 2, point 42).

An interesting case of identification of $A$. astacus specimen caught in a tributary of river Spercheios close to the village Moschochori, Region of Sterea Ellada, took place by one of us (CP) in a Facebook discussion (Fig. 2, point 58), on posted photos provided by Dr. Stamatis Zogaris from the Hellenic Centre of Marine Research during 2015. During the on-line conversation, the presence of the same species was also suggested for the same catchment area close to the nearby village of Amouri (Fig. 2, point 57).

Another A. astacus population was detected near village Achelinada, Kalampaka, Region of Thessaly, based on an uploaded YouTube video. The video presents serving crayfish in a local crayfish festival on August 9, 2011 (Fig. 2, point 44). Boiled A. astacus specimens were also presented on a photo posted by a local news site to promote this festival on 2015 (Fig. 2, point 44). According to Laggis et al. (2017), this population was translocated from Krania (borderline of Regions Western Macedonia and Epirus) during the last $10-15$ years.

A further YouTube video presents boiling A. astacus crayfish on coal (Fig. 2, point 59). The specimens were 
captured by locals on August 12, 2012 close to the city of Orchomenos, Region of Sterea Ellada, without mentioning the exact location of the population. However, the population is present in the catchment area of Kifissos river - Yliki lake system (Kastritsi-Kathariou and Skeparioti, 1990; KastritsiKathariou et al., 1994), representing the southernmost known population of the species in Europe, apart from the populations in the Peloponnisos peninsula.

Information on a significant (and apparently) historic $A$. astacus population in the artificial Argyropouliou lake (=Mati Tyrnavou, Region of Thessaly) were provided by the Environmental Group of the Gymnasium in Argyropouli village. They interviewed (Fig. 2, point 46) locals who said that a crayfish population was present in the area a long ago in very high abundance (water temperature during winter period at 16$18^{\circ} \mathrm{C}$, maximum depth of $7 \mathrm{~m}$ ), which led to the creation of a local co-operative. Crayfishing was performed even professionally by hands, traps and funnel, drum net fish traps (so called daoulia) and crayfish were commercially delivered to the cities of Athens, Ioannina, to other places in Greece and even to Sweden. Maximum total body length of caught crayfish was about $15 \mathrm{~cm}$ with various colors shades (green, black and brown). The population extirpated during 1990s' and according to the locals this happened due to a prolonged dry period and water mis-management for use in agriculture. Moreover, there were unofficial private attempts to restock the lake. The same Environmental Group proceeded to capturing of unspecified crayfish (some individuals with attached hatchlings) from the nearby village of Karya (located at the southern part of Olympos mountain) and released them in an enclosure in the springs of Mati brook, which feeds the lake. This is a case of unofficial restocking of A. astacus, as the species was recently identified by sampling in the source site (Laggis et al., 2017).

Another population in the catchment of river Pinios (Region of Thessaly) was detected close to the village of Ampelonas based on a YouTube uploaded photo collection (Fig. 2, point 47). The species is sporadically caught and it is considered rare in the tributaries of river Pinios, particularly in the intensively cultivated lowlands of the region where intensive agriculture occurs.

Unidentified crayfish were reported (Fig. 2, point 6) to be abundant and living at the same habitat with freshwater crabs (probably Potamon ibericum (Bieberstein)) in the Blue lake (=Galazia Limni) close to village Skra (Axioupoli, Kilkis, Region of Central Macedonia) and in unspecified brooks close to the artificial lake Metalleiou. Both lakes exist on Paiko mountain and belong to the catchment area of Axios river. $A$. astacus samples were also examined by the staff of the local Fisheries Department (G. Michailidis, pers. comm.) captured in the tributaries of Axios river in the area of Kotsadere (=Big river) (spring of Metalleio), as well as close to the villages of Skra, Koupa, and Axioupolis (Perdikaris, 2009). These mountain tributaries which are typical habitats of $A$. astacus, represent an overlapping distribution zone with $A$. torrentium (Karaman (1963), Albrecht (1982), and Kinzelbach (1986) for A. astacus, and Trontelj et al. (2005) and Machino and Holdich (2006) for $A$. torrentium). The presence of $A$. astacus population were confirmed for the first time during 2006 in Melisiotiko river (tributary of Loudias river on the southern part of Paiko mountain) based on the capturing of three adult male specimens (Fig. 2, point 10; Koutrakis et al., 2007; Perdikaris, 2009). Moreover, one more nearby site with $A$. astacus was recently suggested by a local ichthyologist (Fig. 2, point 9) and a sample was also collected in the area by Laggis et al. (2017) (Fig. 2, point 11).

The presence of $A$. astacus was recently suggested by Krstić (2012) and Spirkovski et al. (2012) for Prespa lakes and adjacent tributaries (Fig. 2, point 16), also representing a sympatric zone for $A$. astacus and A. torrentium (see details in Section 3.1.2).

Finally, based on a recently published work on A. astacus genetics (Laggis et al., 2017), sampling was conducted during the period 2009-2013 in 284 sites and led to the collection of 284 specimens from 21 sites. Native and translocated populations in 10 out of 21 locations sampled during this study, were previously unknown to the literature, for example in Tzaravina lake (Fig. 2, point 25), Chani Kaber Aga (Fig. 2, point 31) (Region of Epirus), Krania (Fig. 2, point 33), Pertouli (Fig. 2, point 50) (Region of Thesaly), Skotina (Fig. 2, point 14) and Karya (Fig. 2, point 15) on the mountain Olympos (Region of Western Macedonia) (Laggis et al., 2017; Tab. 1, Supplementary Material).

\subsubsection{Austropotamobius torrentium}

Austropotamobius torrentium is present exclusively in northern Greece, in the Regions of Eastern Macedonia and Thrace, Central and Western Macedonia and historically from one site in the northern borders of the Region of Thessaly (Fig. 3). It is particularly a rheophilic species preferring cold, clear and high quality waters and it is present in tributaries of the following main river systems: Aliakmonas, Axios, Strymonas and Nestos. Historically, it has been also recorded from a spring of Pinios river. The species is also present in the catchment area of Prespes lakes. The presence of the species is still questionable in the area of Grevena (catchment area of Aliakmonas river), in Chalkidiki peninsula and in tributaries of Evros river (the species is present in a mountain tributary of its Bulgarian part; Todorov et al., 2014).

An i nteresting case of crayfish mis-identification was detected in a United Nations Development Program report for Prespes lakes (handling both Megali and Mikri Prespa as a single water body) (Spirkovski et al., 2012). The authors mention the presence of $A$. astacus (as $A$. a. balcanicus) living in the tributaries of the lakes, but the specimens which are shown in the report clearly belong to the A. torrenitum (Fig. 3, point 90). According to the available information, $A$. torrentium was still present during a recent field investigation in all streams and rivers of the Prespa watershed in Former Yougoslav Republic of Macedonia (FYROM) (i.e., around Megali Prespa lake). Perennou et al. (2009) and Krstić (2012) mention both species for FYROM. Therefore, it can be inferred that these species are at least partly overlapping in this region.

The presence of unidentified crayfish populations was proposed in many springs near village Kratero, Florina, Region of Western Macedonia (Fig. 3, point 92). The old name of the village was Rakovo and the crayfish in the local dialect were termed as rakoi. Similarly, there is a walking track in the woods of Nymfeo (Florina) named the "blue track" (=the crayfish travelogue). It was named after the presence of purple- 


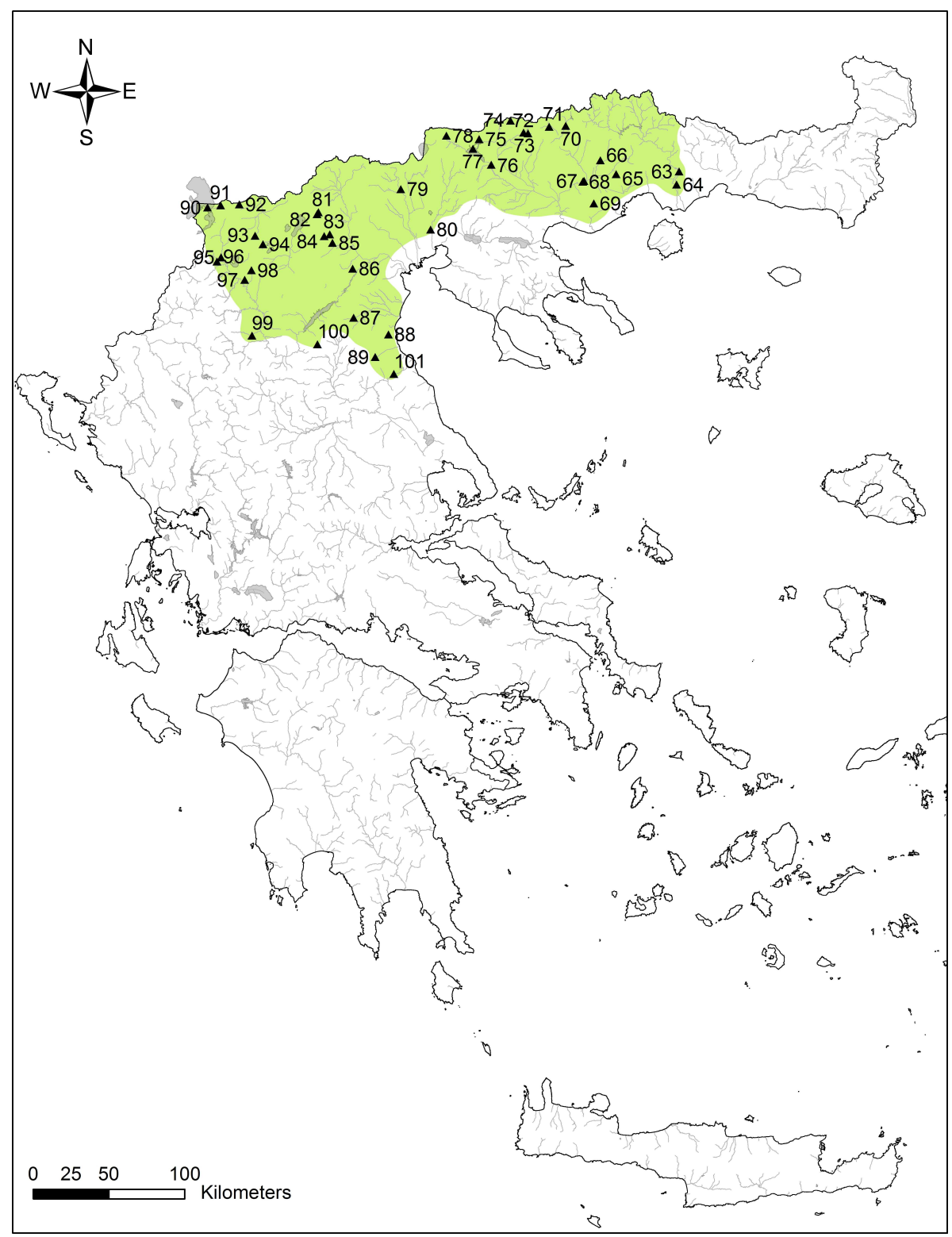

Fig. 3. Distribution area of Austropotamobius torrentium in Greece. Numbers with details follow the sequence of Table 1, Supplementary Material. Original layers from www.geodata.gov.gr.

blue crayfish living in Drosopigiotiko river until 1995 (Fig. 3, point 93). The area has a dense network of mountain brooks, which eventually enter FYROM and are tributaries of Axios river. Moreover, north of the Sklithro village (catchment area of lakes Zazari and Cheimaditida) at a site name Isvoros, there is a waterfall with crayfish (Fig. 3, point 94).

The presence of $A$. torrentium in brooks around the city of Kastoria, Region of Western Macedonia, was recently confirmed based on a Facebook post. Another YouTube video (Fig. 3, point 96) shows locals catching $A$. torrentium in a brook inside Mesopotamia woods close to the city of Kastoria. The presence of species in the catchment area was first reported by Perdikaris (2009) based on six specimens captured east of Kastoria (brook of Koromilia) and north of Neapoli village (brooks of Germas and Vogatsiko), which are all tributaries of river Aliakmonas.

\subsubsection{Astacus leptodactylus}

The only native population of $A$. leptodactylus is found in Evros river. However, the species was translocated in Pamvotida lake (Region of Epirus) and also in the artificial lake of Polyphytou (Region of Western Macedonia) (Fig. 4). The later translocation has led to increased population density and commercial exploitation. One more population seems to be established in Pinios river (close to Ampelonas village) either from early and/or recent traslocation efforts. The presence of the species is possible but still questionable in Cheimaditida lake and Nestos river. It is subject to domestic trade as it was found in restaurants in Nisi village of the artificial Agra lake and on Nisi island of Pamvotida lake.

Trading of $A$. leptodactylus is shown on a YouTube video (Fig. 4, point 111). A seller from Servia (Kozani, Region of 


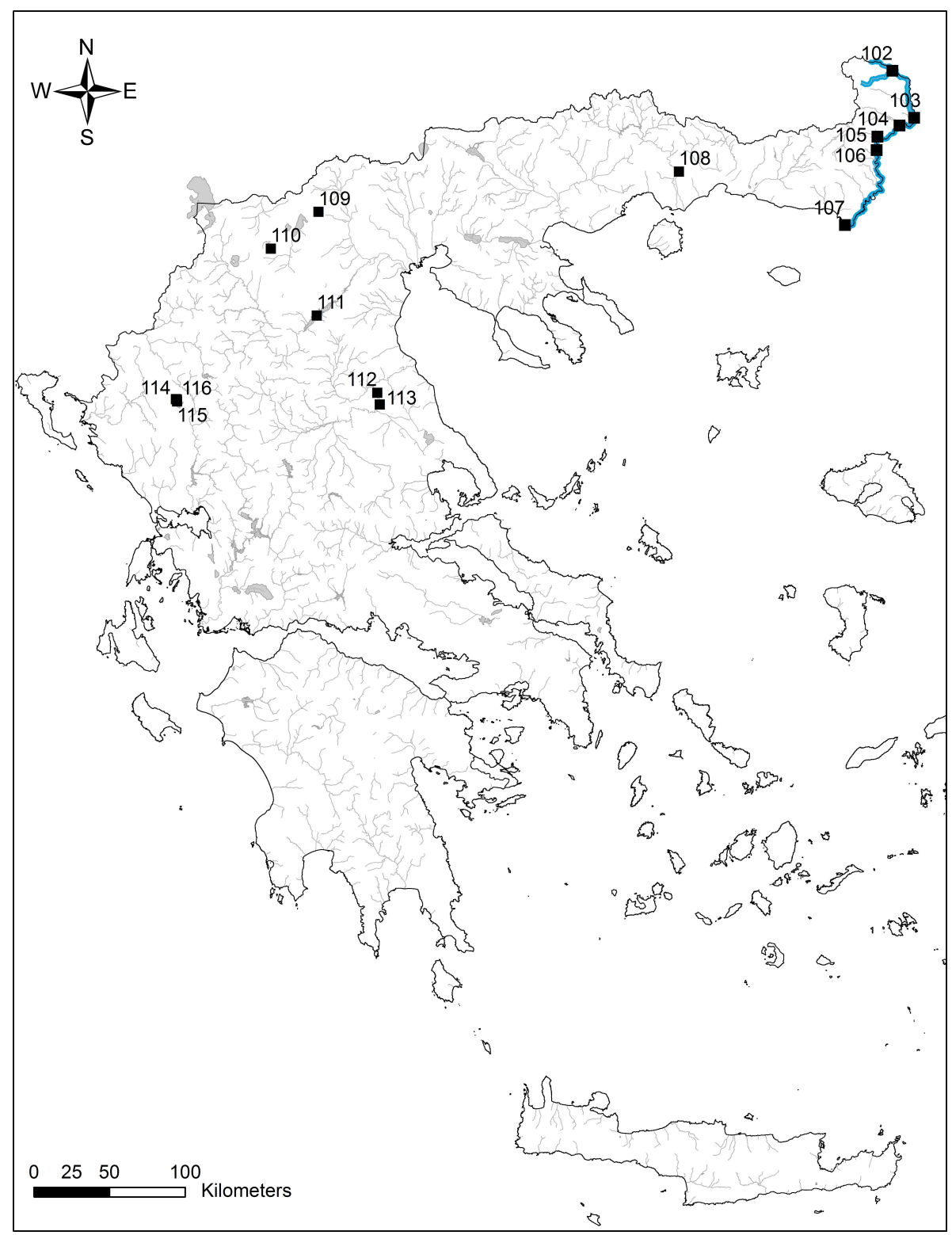

Fig. 4. Distribution area and translocations of Astacus leptodactylus in Greece. Blue line represents the native range and the rest of the squares are locations were it was translocated. Numbers with details follow the sequence of Table 1, Supplementary Material. Original layers from www. geodata.gov.gr.

Western Macedonia) is offering crayfish, some of them with extruded eggs, in two polysterine boxes to the locals of Ampelonas village, Larissa, Region of Thessaly. According to comments of this post, the crayfish were harvested with daoulia or nets in the lake (i.e., the artificial lake Polyfytou) close to the city of Servia. Based on a local website (Fig. 4, point 111) the flourishing A. leptodactylus population in the Polyfytou lake sustains an official production of 300 tons (but unofficially estimated to a multiple level), which are mainly exported to France, Italy, UK and to Scandinavian countries. The number of active fishermen increased within the last two years from 45 to 113 , with mean per capita catch reaching $500 \mathrm{~kg}$ on a weekly basis. Concerning the trade chain prices, fishermen sell their catch to a local packaging facility for $€ 3$ per $\mathrm{kg}$ and fishmongers in the export destinations sell for $€ 8$
15 per kg (Anonymus, 2016). This case represents a recently translocated/established and the first commercially exploited A. leptodactylus population in Greece.

The species is also captured in Pinios river close to Ampelonas village, Region of Thessaly (Fig. 4, point 112), indicating a translocated and rather well-established population, together with the indigenous $A$. astacus population which is present in this river. This is a suspected case of secondary or at least tertiary (from lake Polyphytou) translocation, given that there is unverified evidence published in Koutrakis et al. (2007) that $A$. leptodactylus was released in Pinios river already from the 1980s' (Fig. 4, point 113).

The species is also shown on a YouTube video in a glass aquarium of a restaurant on Nisi, Pamvotida lake, Region of Epirus (Fig. 4, point 116), suggesting that the domestic trade of 


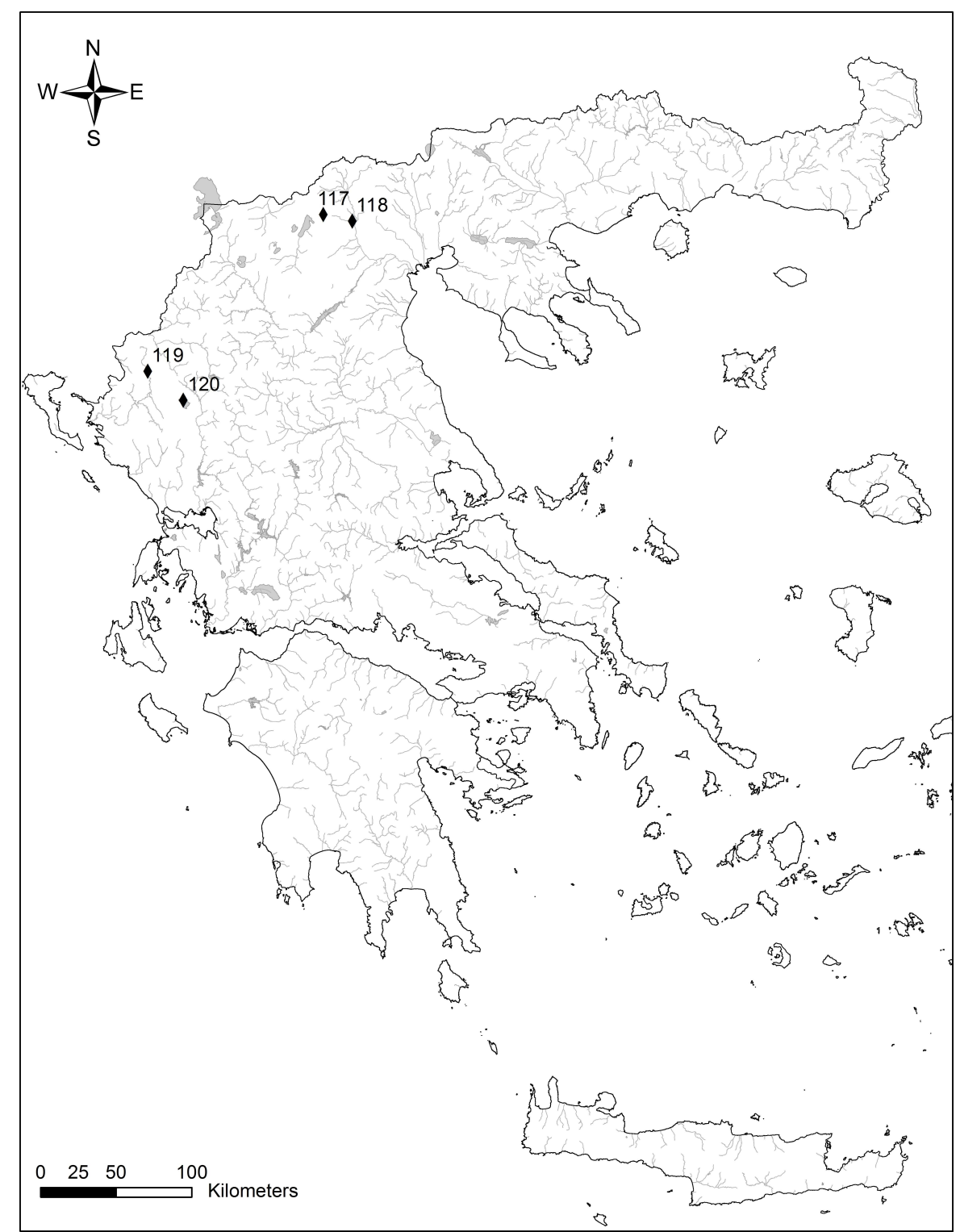

Fig. 5. Sites of introductions from abroad and subsequent translocation or range expansion of Pacifastacus leniusculus in Greece. Numbers with details follow the sequence of Table 1, Supplementary Material. Original layers from www.geodata.gov.gr.

species exists with suitable-sized stocks supporting it. The presence of the species at two locations in Pamvotida lake was recently documented by samples in 2015 (Perdikaris and Georgiadis, 2017).

\subsubsection{Pacifastacus leniusculus}

The species was originally introduced during the $1980 \mathrm{~s}$, to the artificial Agra lake and in Kalamas river, originating from Germany (in both systems) and from Sweden (Simontorp hatchery) in the later. Until recently, the only established population known for this species in Greece existed in the artificial Agra lake, Region of Western Macedonia (Koutrakis et al., 2007), where it sustains local crayfish trapping activity (Fig. 5). The species is clearly shown on a YouTube video served during a crayfish festival in Nisi village (Fig. 5, point 117). However, there is strong evidence that it has escaped from the lake outflow to a tributary of Aliakmonas river. During a visit by one of us (CP) in a nearby restaurant serving crayfish in August 2013, the owner argued that the species has escaped from the lake overflow to the recipient tributary of Aliakmonas river, at least down to the city of Skydra, in which it is intensively captured with funnel, drum net fish traps. This is the first evidence that the species escaped from Agra lake to this river, which contains a population of $A$. torrentium; Fig. 5, point 118 . It remains unknown whether this population is a chronic carrier of the crayfish plague pathogen. On the other hand, the introduced juveniles in Kalamas river faced significant mortalities during the acclimation period and this past introduction is regarded as unsuccessful, as no specimen of the species has been captured up today. Similarly to $A$. leptodactylus, the species is subject to trade. On another YouTube video (Fig. 5, point 120), the species is shown in a glass aquarium of a restaurant (the same restaurant mentioned 


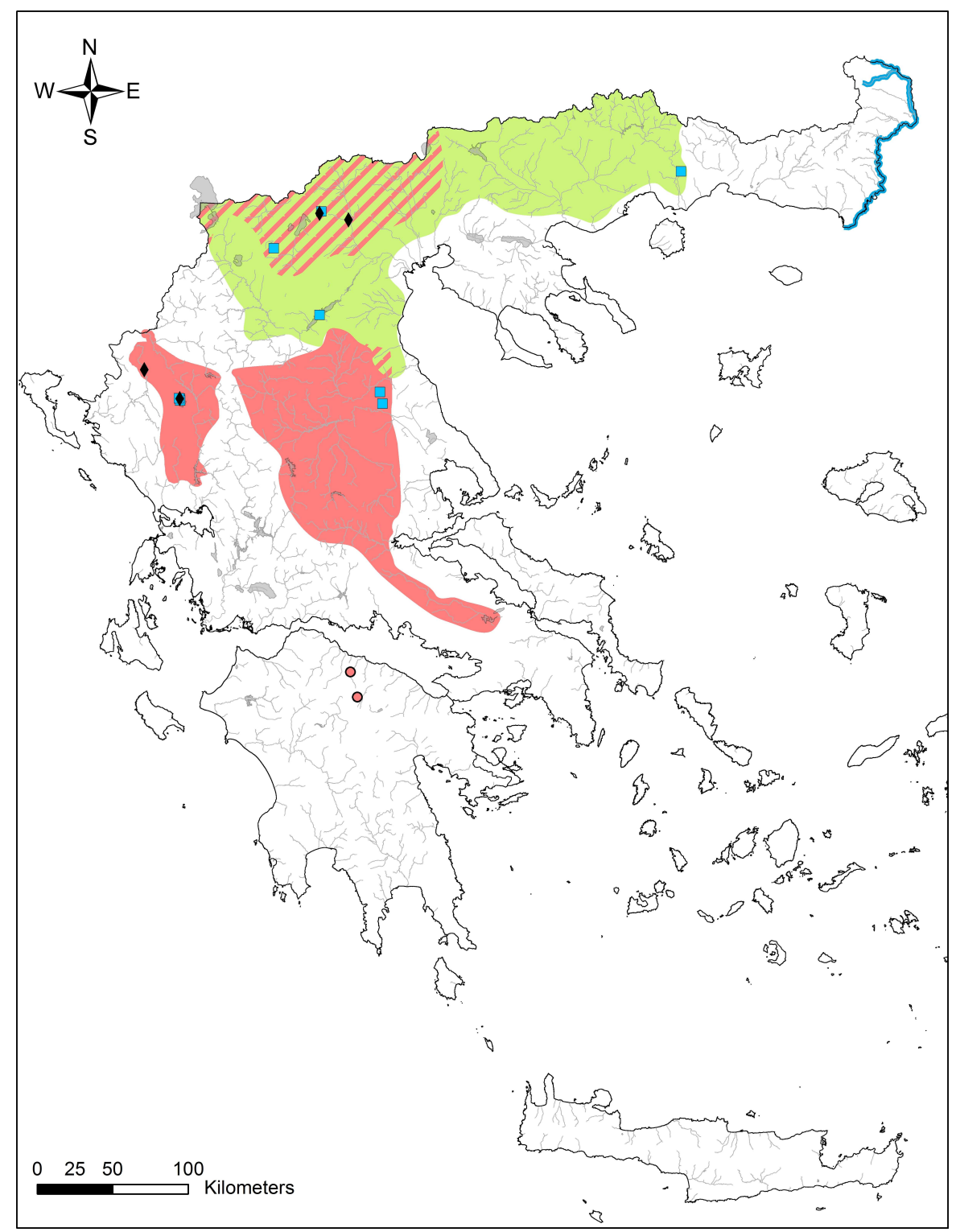

Fig. 6. Distribution areas of freshwater crayfish in Greece. Astacus astacus: red areas and circles; Austropotamobious torrentium: green area; Astacus leptodactylus: blue line and squares (translocations); Pacifastacus leniusculus: diamonds (introductions, translocation and range expansion); mixed distribution zone of $A$. astacus and A. torrentium: hatched area. Original layers from www.geodata.gov.gr.

in Section 3.1.3) on Nisi island (within Pamvotida lake, which is located at a distance of $150 \mathrm{~km}$ in a straight line from Agra lake), suggesting that the species is traded and possibly originates from Agra lake. However, no free-leaving specimens have been caught in Pamvotida lake so far.

Figure 6 presents the combined distributions of all the aforementioned species and all the respective records are included in Table 1, Supplementary Material.

\section{Discussion}

One could argue about the credibility of records coming from non-published sources (i.e., whether the locality information or the identification from locals are accurate, etc.). Nevertheless, it is a trend where citizen-science data emerge more often due to the current means of media and information dissemination. Software applications for smartphones promote this idea of species occurrence reporting with more appealing interfaces and attribution allurements (e.g., Open Data Kit, Sapelli, GeoODK, CyberTracker, and more).

This work tries to utilize various data sources and raise their credibility through verification to the best of the authors' knowledge. In most cases, it was fairly easy to ascertain with relative confidence the identification of the species and in the majority of the instances our findings coincide with the ones reported from the creators of the media used. This verifies that more and more scientific data are being generated from participatory monitoring programs on various levels (e.g., regional, national or even global) and can be effectively used by the scientific community.

Concerning freshwater crayfish, the works by Holdich (2002, 2003), Skurdal and Taugbøl (2002) and Lewis (2002) 
on continental level, presented country lists for each species and/ or pan-European maps with gross information (e.g., presence/ absence of crayfish per country based on color differences or highlighted areas with known occurrence). Initially based on CRAYNET project inputs, Souty-Gosset et al. (2006) and Kouba et al. (2014) presented a more detailed pan-European dotoccurrence maps (based on $50 \times 50 \mathrm{~km}$ grids) for each species (ICS and NICS), with the presumed native ranges highlighted. The earlier crayfish distribution maps focusing on Greece were published for A. astacus by Koukoura (1973) for the central part of northern Greece and Theocharis (1986) for the Region of Epirus. Subsequently, Kinzelbach (1986) discussed the gross limits of $A$. astacus and $A$. torrentium with emphasis on their southern limits but without a map presentation. The only available country-wide maps of all four species were presented by Koutrakis et al. (2007) and Perdikaris (2009). Accordingly, the current work presents the most updated and detailed countrywide GIS-based maps for all species with their most probable distribution areas, combining deep revision of the available literature and citizen-science data.

Concerning $A$. astacus, the current work updates and expands the known distribution range of the species. The recorded mean altitude of its habitats was $552 \mathrm{~m}$ (ranging from 8 to $1348 \mathrm{~m}$ ), which is higher compared to the rest of the crayfish species. Overall, its distribution is represented by three disconnected zones. However, the collections of specimens in Krania (Laggis et al., 2017), brings closer two of these zones (i.e., the zone in western and central Greece). Greek populations represent the southernmost $A$. astacus populations in Europe (cf. Kouba et al., 2014) and the second globally after the introduced populations in northern Morocco (Benabid and Khodari, 2000). The finding of these populations as well as the population in Spercheios river is important, as they fill existing gaps in A. astacus distribution in Greece

The $A$. torrentium populations are distributed exclusively in the northern part of the country, apparently without any significant discontinuity between Nestos river to the east end and Aliakmonas river to the west end of this zone. With the addition of new records, a more densely populated zone is depicted. The vast majority of the populations are lotic, located mainly in mountainous terrain (mean altitude: $464 \mathrm{~m}$, ranging from 19 to $1043 \mathrm{~m}$ ) with forest cover, reflecting their sensitivity to siltation and habitat alteration (Koutrakis et al., 2007).

Indigenous $A$. leptodactylus populations are exclusively found in Evros river which represents the natural border with Turkey. However, this species is recently subjected to significant domestic trade, which has led to successful translocations to at least three locations in two regions, far outside its native range. The recorded mean altitude of its habitats was $202 \mathrm{~m}$ (ranging from 1 to $606 \mathrm{~m}$ ), which is affected by the much higher altitudes of the habitats where the species was translocated, compared to its native range in Evros river. Translocations represent a major threat to the other (i.e., two indigenous species) due to its life history traits (i.e., greater size, fecundity, high population density), moderate levels of resistance to crayfish plague and risk of displacement (Holdich, 1999; Stucki and Romer, 2001; Tricarico et al., 2010), as the existing translocated populations of $A$. leptodactylus are located inside the A. astacus and $A$. torrentium distribution areas (Fig. 6).
Finally, $P$. leniusculus is still confined in a particular catchment area in Central Macedonia. However, illegal translocations to other catchments is possible (Perdikaris and Georgiadis, 2017 and Fig. 6). Moreover, the issue of whether this is a plague-carrying population has not been resolved yet, thus signifying that trading could be a potentially devastating practice for indigenous species. In fact, EU Regulation No. 1143/ 2014 and Commission Implementing Regulation No. 2016/1141 forbid keeping, translocating, reproducing, selling, etc., of such species. However, no official implementation has yet been enforced, although both regulations are automatically parts of the national legislation, with no ratification requirement.

Survival of $A$. astacus and A. leptodactylus in glacial refugia has been documented for Western Balkans (Schrimpf et al., 2014), for the vicinity of the Black Sea (Minor Asia or the Balkan peninsula; Maguire et al., 2014) and recently suggested for the Rhine catchment (Schrimpf et al., 2017). However, current distribution of both species has been largely dictated by human-mediated activities (i.e., stocking, translocation, habitat alterations, and introductions). A recent genetic work based exclusively on $A$. astacus samples from Greece using mitochondrial and nuclear microsatellite markers, showed the existence of two novel phylogenetic clades and a high number of unique haplotypes. Greece represents the older center of expansion/glacial refugium compared to the eastern Black Sea and Western Balkans. On population level, eight putative barriers were identified separating nine distinct clusters, highlighting the role of geographic landscape and translocations (Laggis et al., 2017). These genetic data are in alignment to the zoogeographic and location-specific data presented in the current work, clarifying issues related to geographic isolation and the role of translocations in shaping the contemporary distribution pattern of the species.

Concerning $A$. torrentium, the only available genetic data using mitochondrial markers are related to a small number of selected Greek populations (Trontelj et al., 2005; Klobučar et al., 2013). The northern-central Dinaric region is the predominant genetic diversity and radiation center for this species. Populations in southern Balkan peninsula (including Northern Greece), though most recent in evolutionary terms are characterized by high nucleotide and lineage diversity (existence of nine-sublineages). Such diversity indicates extensive survival in glacial refugium during Pleistocene, although pre-Plestocene southward expansion possibly originated from the Dinaric populations (Klobučar et al., 2013). At this point, it should be noted that the rule that the southern it is, the more genetically diverse a crayfish population is, might not be valid for a typical cold-water species such as $A$. torrentium for which the mean annual water inhabited does not exceed $10^{\circ} \mathrm{C}$, if high temperatures act also as barriers. Accordingly, only a part of more adaptable stocks might flourish there. Nevertheless, extensive genetic work is needed involving sufficient sampling of as more as possible subdivided populations to fully resolve the genetic status of A. torrenitum in Greece and beyond.

Protection of ICS should be an obvious priority and at the same time, deliberate translocations and unregistered trade should be controlled. Moreover, there is an urgent need to sensitize and raise the awareness of local communities and to reform and modernize the available legislation, particularly according to the EU regulations related to NICS. The use of crayfish (i.e., A. astacus and particularly A. torrentium) as 
flagship and heritage species (Füreder and Reynolds, 2003), in NATURA designated areas, is a reasonable mean not only to protect them per se, but also to indirectly protect their habitats. Present work could help along with current and future generated genetic data to identify appropriate conservation management units (as defined by Moritz, 1994) for both threatened species $(i$. e., A. astacus and A.torrentium), in order to conserve the existing genetic diversity. These actions should also be complemented by close co-operation between engineers and aquatic biologists in works related to the aquatic environment, funding of monitoring programmes for the populations and assessing and minimizing the risk posed by NICS available in pet trade (conventional and internet-based). Actually, P. leniusculus might not be the only hazardous NICS as more non-indigenous species are still potentially undiscovered in the wild or might appear in the future due to pet-traded ornamentals (Papavlasopoulou et al., 2014).

In conclusion, the current work documented the presence of several crayfish populations belonging to four species, which span over large parts of continental Greece. The dataset and the relevant maps include native populations previously unknown from the literature. Translocated populations, as well as certain cases of historically flourishing stocks, which have been severely affected or even vanished are presented/ depicted. Moreover, the generated maps, combining data from extensive literature review and citizen-science: (a) depict in detail the overall geographic spread of each species; (b) visually reveal the overlapping zones between $A$. astacus and A. torrentium; and (c) present the intrastate translocations of $A$. leptodactylus and the introductions of $P$. leniusculus both in core habitats of $A$. astacus and A. torrentium.

\section{Supplementary Material}

Table 1.

The Supplementary Material is available at http://www. kmae-journal.org/10.1051/kmae/2017042/olm.

\section{References in supplementary material}

Athanassopoulos (1935), Evaggelidis (2001), Kevrekidis et al. (1999), Koutrakis et al. (2003), Koutrakis et al. (2005b), Neophytou et al. (1993) and Paschos and Kagalou (1995).

Acknowledgements. A.K. acknowledges the Ministry of Education, Youth and Sports of the Czech Republic Projects "CENAKVA" (No. CZ.1.05/2.1.00/01.0024) and "CENAKVA II" (No. LO1205 under the NPU I program).

\section{References}

Albrecht H. 1982. Das System der europäischen Flußkrebse (Decapoda, Astacidae): Vorschlag und Begründung. Mitt Hamb Zool Mus Inst 79: 187-210.

Alderman DJ. 1996. Geographical spread of bacterial and fungal diseases of crustaceans. Rev Sci Tech Off Int Epiz 15: 603-632.

Anonymus. 2016. Thisavros oi karavides tis Kozanis (Treasure, the crayfish of Kozani). Alieftika Nea 412: 80-84 (in Greek).

Athanassopoulos G. 1935. Particularité de la distribution de l'ichthyofaune des eaux douces en Grèce. Verh Internat Verein Theor Angew Limnol [Jahrgang 1934] 7: 117-121.
Balss H. 1928. Süßwasserdecapoden aus Mazedonien. Zool Anz 75: 120-122.

Benabid M, Khodari M. 2000. Status of Astacus astacus in Moroccan aquatic ecosystems. Crayfish News 22: 8-10.

Bott R. 1972. Besiedlungsgeschichte und Systematic der Astaciden West-Europas unter besonderer Berücksichtung der Schweiz. Rev Suisse de Zool 79: 387-408.

De Vaugelas J, Leyendecker V, Leca H, et al. 2011. Use of smartphones (iPhone, Android, etc.) for the field identification of European crayfish. Knowl Manag Aquat Ecosyst 401: 34.

Delaney DG, Sperling CD, Adams CS, Leung B. 2008. Marine invasive species: validation of citizen science and implications for national monitoring networks. Biol Invasions 10: 117-128.

Evaggelidis E. 2001. I limni ton kiknon, o ygroviotopos Agra-VrittonNisiou (The swan lake, the wetland of Agra-Vritton-Nisiou). Edessa, 88 p. (in Greek).

Füreder L, Reynolds JD. 2003. Is Austropotamobius pallipes a good bioindicator? Bull Fr Pêche Piscic 370-371: 157-163.

Garcia C, Montgomery E, Krug J, Dagit R. 2015. Removal efforts and ecosystem effects of invasive red swamp crayfish (Procambarus clarkii) in Topanga Creek, California. Bull South Calif Acad Sci 114: 12-21.

Holdich DM. 1999. The negative effects of established crayfish introductions. In Gherardi F,Holdich DM, eds.Crayfish in Europe as alien species: how to make the best of a bad situation? Crustacean Issues, Vol. 11. Rotterdam: A.A. Balkema, pp. 31-47.

Holdich DM. 2002. Present distribution of crayfish in Europe and some adjoining countries. Bull Fr Pêche Piscic 367: 611-650.

Holdich DM. 2003. Crayfish in Europe - an overview of taxonomy, legislation, distribution, and crayfish plague outbreaks. In Holdich DM, Sibley PJ, eds. Management and conservation of crayfish. Bristol: Environment Agency, pp. 15-34.

Karaman MS. 1963. Studie der Astacidae (Crustacea, Decapoda). Hydrobiologia (The Hague) 22: 111-132.

Kastritsi-Kathariou I, Skeparioti E. 1990. Meleti aytohthona plythismou tis karavidas tou glykou nerou Astacus astacus proerxomenis apo ton Viotiko Kifisso (Study on indigenous population of freshwater crayfish Astacus astacus from Viotian river Kifisos). Athens University, Zoology Laboratory, 85 p. (in Greek).

Kastritsi-Kathariou I, Nikokirakis M, Armakas D, Kazanoglou A. 1994. Meleti tis karavidas Astacus astacus proerxomenis apo fysiko plythismo viotyopou ston Orhomeno Viotias (Study on the crayfish Astacus astacus from the native population in Orchomenos Viotias. 2nd Report to the Greek Ministry of Agriculture. Athens: Athens University, School of Biology, Zoology Department, 115 p. (in Greek).

Kevrekidis K, Papalexiou E, Sbiliri E, Passas N, Kirkalatslis P. 1999. Eglimatismos kai ektrofi tis karavidas Astacus astacus Linnaeus sto ergastirio (Acclimation and farming of crayfish Astacus astacus Linnaeus in the laboratory). Alieftika Nea 216: 95-98 (in Greek).

Kinzelbach R. 1986. The southern limit of the crayfishes species Astacus torrentium and A. astacus in Greece. Zool Middle East 1: 145-146.

Klobučar GI, Podnar M, Jelić M, et al. 2013. Role of the Dinaric Karst (western Balkans) in shaping the phylogeographic structure of the threatened crayfish Austropotamobius torrentium. Freshw Biol 58: 1089-1105.

Kouba A, Petrusek A, Kozák P. 2014. Continental-wide distribution of crayfish species in Europe: update and maps. Knowl Manag Aquat Ecosyst 413: 05.

Koukoura A. 1973. Simboli is tin meletin ton dekapodon karkinoidon tis Ellados (Contribution to the study of decapod crustaceans in Greece). Elleniki Okeanologia kai Limnologia (Athens) 11:745-769 (in Greek).

Koutrakis E, Katsaiti L, Kallianiotis A, et al. 2003. The aquatic macrofauna of Cave Aggitis (Maaras, Drama). Preliminary results. In: Proceedings of the 11th Hellenic Congress of Ichthyologists, 
Preveza, Greece, 10-14 March 2003, pp. 83-86 (in Greek with English abstract).

Koutrakis ET, Machino Y, Kallianiotis A, Holdich DM. 2005a. Austropotamobius torrentium (Schrank, 1803) in the Aggitis Cave (northern Greece). Is it a cavedwelling species? Bull Fr Pêche Piscic 376/377: 529-538.

Koutrakis ET, Katsaiti L, Kallianiotis A, Economidis PS. 2005b. The stone crayfish Austropotamobius torrentium in the Aggitis Cave (river Aggitis springs, Drama). In: Proceedings of the 12th Hellenic Congress of Ichthyologists, Drama, Greece, 13-16 October 2005, pp. 316-319 (in Greek with English abstract).

Koutrakis E, Perdikaris C, Machino Y, Savvidis G, Margaris N. 2007. Distribution, recent mortalities and conservation measures of crayfish in Hellenic fresh waters. Bull Fr Pêche Piscic 385: 25-44.

Krstić SS. 2012. Environmental changes in lakes catchments as a trigger for rapid eutrophication - a Prespa lake case study. In: Piacentini T, ed. Studies on environmental and applied geomorphology. Rijeka, Croatia: InTech, pp. 63-118.

Ladas K. 2013. In the fever of Doxa. Geodromio 18: 9-23 (in Greek).

Laggis A, Baxevanis AD, Charalampidou A, Maniatsi S, Triantafyllidis A, Abatzopoulos TJ. 2017. Microevolution of the noble crayfish (Astacus astacus) in the Southern Balkan peninsula. BMC Evol Biol 17: 112.

Lewis SD. 2002. Crayfish of commercial importance. Pacifastacus. In: Holdich DM, ed. Biology of freshwater crayfish. Oxford: Blackwell Science Ltd., pp. 511-540.

MachinoY, Holdich DM. 2006. Distribution of crayfish in Europe and adjoining countries: updates and comments. Freshw Crayfish 15: 292-323.

Maguire I, Podnar M, Jelić M, et al. 2014. Two distinct evolutionary lineages of the Astacus leptodactylus species-complex (Decapoda: Astacidae) inferred by phylogenetic analyses. Invertebr Syst 28: 117-123.

Moritz C. 1994. Defining 'evolutionary significant units' for conservation. Trends Ecol Evol 9: 373-375.

Neophytou C, Tiagos P, Revis D. 1993. Meleti tis pyknotitas ton makro-venthikon organismon sto rema "Myloi" Angistrou (Study of the density of macro-benthic organisms in the creek "Myloi" Angistrou). Geotechnika Epistimonika Themata (Thessaloniki) 4: 44-71 (in Greek with English summary).

Nikolaou C. 2004. Biologia tis karavidas Astacus fluviatilis: I periptosi tis karavidas tou potamou Kalama kai tis texnitis limnis Aoou (Biology of crayfish Astacus fluviatilis: the case of crayfish in the river Kalamas and artificial lake of Aoos), Graduate thesis. Department of Aquaculture and Fisheries, Technological Educational Institute of Epirus, 117 p. (in Greek).

Papavlasopoulou I, Perdikaris C, Vardakas L, Paschos I. 2014. Enemy at the gates: introduction potential of non-indigenous freshwater crayfish in Greece via the aquarium trade. Cent Eur J Biol 9: 11-18.

Papakonstantinou K, ed. 2003. The wetland of lake Tsivlou. Center for Environmental Education of Akrata, 56 p (in Greek).

Paschos I, Kagalou I. 1995. Diaxiristiki meleti Limnis Pamvotidas (Management study of lake Pamvotis). Epirus, Greece: Prefecture of Ioannina, 600 p. (in Greek).

Perdikaris C. 2009. Biology and distribution of the populations of crayfish species in the freshwaters of Greece, $\mathrm{PhD}$ thesis. Greece: University of the Aegean (in Greek).

Perdikaris C, Georgiadis C. 2017. Co-occurrence of narrow-clawed crayfish (Astacus leptodactylus sensu lato) and noble crayfish (Astacus astacus L.) in the southwestern Balkans: the case of lake Pamvotida (NW Greece). North West J Zool 13: 18-26.

Perdikaris C, Nathanailides C, Ergolavou A, Paschos I. $2005 \mathrm{a}$. Freshwater crayfish (Astacus astacus L.) in the river Kalamas: species and sex distinction, sex ratio, length-frequency analysis and growth. In: Proceedings of the 12th Hellenic Congress of Ichthyologists. Drama, Greece, 13-16 October 2005, pp. 180184 (in Greek with English abstract).

Perdikaris C, Koutrakis M, Machino Y. 2005b. Overview of crayfish situation in Greece. Crayfish News: IAA Newsl 27: 5-7.

Perdikaris C, Koutrakis E, Saraglidou V, Margaris N. 2007. Occurrence of the narrow-clawed crayfish Astacus leptodactylus Eschscholtz, 1823 in the river Evros in Greece. Bull Fr Pêche Piscic 385: 45-52.

Perennou C, Gletsos M, Chauvelon P, et al. 2009. Development of a transboundary monitoring system for the prespa park area, annexes, aghios germanos. WWF-Greece/MAVA Foundation.

Savvidis G. 2005a. Ekthesi-gnomatefsi epi tou fenomenou tou mazikou thanatou karavidon ston Potamo Kalama kai tous parapotamous tou Gormo kai Limpousda stin periohi Parakalamou tou N. Ioanninon (Report on the massive crayfish mortalities incident in Kalamas river and its tributaries Gorno and Limpousda, Parakalamos, Ioannina Prefecture). Report n 1305/15-09-2005. National Agricultural Research Foundation, 11 p. (in Greek).

Savvidis G. 2005b. Simpliromatiki ekthesi epi tou fenomenou tou mazikou thanatou karavidon ston Potamo Kalama kai tous parapotamous tou Gormo kai Limpousda stin periohi Parakalamou tou N. Ioanninon (Supplementary report on the massive crayfish mortalities incident in Kalamas river and its tributaries Gorno and Limpousda, Parakalamos, Ioannina Prefecture). Report n 1527/31-10-2005. National Agricultural Research Foundation, 3 p. (in Greek).

Schrimpf A, Theissinger K, Dahlem J, et al. 2014. Phylogeography of noble crayfish (Astacus astacus) reveals multiple refugia. Freshw Biol 59: 761-776.

Schrimpf A, Piscione M, Cammaerts R, et al. 2017. Genetic characterization of Western European noble crayfish populations (Astacus astacus) for advanced conservation management strategies. Conserv Genet DOI: 10.1007/s10592-017-0981-3.

Skurdal J, Taugbøl T. 2002. Crayfish of commercial importance. Astacus. In: Holdich DM, ed. Biology of freshwater crayfish. Oxford: Blackwell Science Ltd., pp. 467-510.

Souty-Grosset C, Holdich DM, Noël PY, Reynolds JD, Haffner P, eds. 2006. Atlas of crayfish in Europe. Collection Patrimoines Naturels, Vol. 64. Paris: Muséum National d'Histoire Naturelle, $187 \mathrm{p}$.

Spirkovski Z, Ilik-Boeva D, Talevski T. 2012. The fish of Prespa. $U N D P, 146 \mathrm{p}$.

Stucki TP, Romer J. 2001. Will Astacus leptodactylus displace Astacus astacus and Austropotamobius torrentiumin lake Ägeri, Switzerland? Aquat Sci 63: 477-489.

Theocharis VS. 1986. La pêche à l'écrevisse dans la région d'Hipiros en Grèce. L'Astaciculteur de France 8: 4-10.

Todorov M, Antonova V, Hubenov Z, Ihtimanska M, Kenderov L, Trichkova T, Varadinova E, Deltshev C. 2014. Distribution and current status of stone crayfish populations Austropotamobius torrentium (Decapoda: Astacidae) in Natura 2000 protected areas in Bulgaria. Acta Zool Bulg 66: 181-202.

Trontelj P, Machino Y, Sket B. 2005. Phylogenetic and phylogeographic relationships in the crayfish genus Austropotamobius inferred from mitochondrial COI gene sequences. Mol Phylogenet Evol 34: 212-226.

Tricarico E, Vilizzi L, Gherardi F, Copp GH. 2010. Calibration of FIISK, an invasiveness screening tool for nonnative freshwater invertebrates. Risk Anal 30: 285-292.

Zenetos A, Koutsogiannopoulos D, Ovalis P, Poursanidis D. 2013. The role played by citizen scientists in monitoring marine alien species in Greece. Cah Biol Mar 54: 419-426.

Cite this article as: Perdikaris C, Konstantinidis E, Georgiadis C, Kouba A. 2017. Freshwater crayfish distribution update and maps for Greece: combining literature and citizen-science data. Knowl. Manag. Aquat. Ecosyst., 418, 51. 